\title{
Forecasting Greenhouse Gas Emissions and Sustainable Growth in Montenegro: a SVAR Approach
}

\author{
Milica Muhadinovic*, Gordana Djurovic, Martin M. Bojaj \\ Faculty of Economics, University of Montenegro, 37 Jovana Tomasevica, 81000 Podgorica, Montenegro
}

Received: 28 August 2020

Accepted: 20 January 2021

\begin{abstract}
This paper uses a recursive structural vector autoregression method to investigate and forecast the linkage and causality between greenhouse gas emissions (GHG) and Gross Domestic Product (GDP) in Montenegro empirically from 2006:1 to 2015:12, and out-of-sample 24-month horizon forecasting from 2016:1 to 2017:12. It is the first time that GDP and GHG are modeled and predicted for the economy of Montenegro using the SVAR approach. We examine an individual SVAR model to forecast GDP. The model uses GDP growth and GHG emissions expressed in $\mathrm{CO}_{2}$ eq by sectors as endogenous determinants. The GHG sectors are energy, industrial process, agriculture and land, and waste. Alternative forecasting scenarios, impulse response functions and variance decomposition of forecast errors are interpreted in combination with expectations. We reveal that the sectors of agriculture and land and energy contribution explain $83.41 \%$ of the movement of GDP at the 24-month horizon.

The paper provides macroprudential policymakers with an in-depth understanding of the GHG emissions expressed in $\mathrm{CO}_{2}$ eq by sectors play in sustainable growth in Montenegro.
\end{abstract}

Keywords: Macroeconometric Forecasting, GDP, GHG emissions, SVAR

\section{Introduction}

In the last few decades, the unfavorable impact of economic growth on environmental quality began gaining popularity as emissions of carbon dioxide $\left(\mathrm{CO}_{2}\right)$ increased, combined with global warming and climate change. These problems became a topic of thorough research in academic circles.

Understanding the nexus $\mathrm{CO}_{2}$ emissions and economic growth helps economies in formulating

*e-mail: milicamuhadinovic@gmail.com energy policies and developing energy resources in sustainable ways [1]. Montenegro ratified the United Nations Framework Convention on Climate Change (UNFCCC) after regaining independence in 2006 and became a non-Annex-1 party to the Convention on January $27^{\text {th }}, 2007$. The Kyoto Protocol was ratified on March 27 th, 2007 , and Montenegro became a nonAnnex-B party on September $2^{\text {nd }}, 2007$. By ratifying the UNFCCC and the Kyoto Protocol, Montenegro joined countries sharing the same concerns and undertaking an active role in international efforts to address climate change (CC) [2].

At the $21^{\text {st }}$ Conference of the Parties (COP21) of the UNFCCC, held in Paris from November $30^{\text {th }}$ to 
December $12^{\text {th }}, 2015$, the Paris Agreement was adopted as a global agreement on climate change, which seeks to strengthen the global response to the threat of climate change [3]. The main goal was determined by the countries "to keep the increase in the global average temperature well below $2^{\circ} \mathrm{C}$ compared to the pre-industrial period, and to make efforts to limit the temperature rise to $1.5^{\circ} \mathrm{C}$ above pre-industrial levels, recognizing that this would significantly reduce the risks and impacts of climate change" (Art. 2). The Paris Agreement recognizes that the long-term objectives set out in Articles 2 and 4.1 will be achieved over time and therefore supports the aggregation of overall and individual ambitions over time.

On October $5^{\text {th }} 2016$, the threshold for the entry into force of the Paris Agreement was achieved. The Paris Agreement entered into force on November $4^{\text {th }}, 2016$, thirty days after the date on which at least 55 Parties to the Convention accounting in total for at least an estimated $55 \%$ of the total global greenhouse gas emissions have deposited their instruments of ratification, acceptance, approval or accession with the Depositary. To this date, 189 Parties have ratified the Agreement, out of 197 Parties to the Convention [4]. Nationally determined contributions (NDCs) are submitted every five years to the Secretariat of the UNFCCC.

The Obama administration accepted the Paris Agreement in August 2016, without submitting the instrument to the Senate for its advice and consent to ratification. The U.S. accordingly became a party to the Agreement when it entered into force in November 2016. In June 2017, President Trump (i.e. the Government of USA) notified the UN Secretary-General of its decision to withdraw from the Agreement, which took effect on November $4^{\text {th, }} 2020$, following article 28 (1) and (2) of the Agreement [5]. However, President-elect Biden announced the USA will reenter the Paris Agreement as early as February 2021.

Today, the EU leads in implementing Paris climate commitments, as a global green player. The European Green Deal, presented on December $11^{\text {th }}, 2019$, provides a roadmap for the EU to become the world's first climate-neutral continent by 2050. The Green Deal presents the necessary investments and available funding tools and explains how to ensure a fair and comprehensive transition, covering all sectors of the economy, especially transport, energy, agriculture, buildings, and industries such as steel, cement, ICT, textiles, and chemicals [6].

The European Union is already doing well in reducing greenhouse gas emissions while maintaining economic growth. Emissions in 2018 were 23\% lower than in 1990, while the Union's GDP grew by $61 \%$ in the same period [7]. On March $4^{\text {th }} 2020$, as part of the European Green Deal, the European Commission adopted a legislative proposal for a European Climate Law that sets the ambitious objective for the EU to become climate-neutral by 2050 (a legally binding
EU-wide common target of net-zero GHG emissions by 2050 i.e. emissions of GHG must not exceed removals) and establishes a framework for achieving that objective. On September $17^{\text {th }} 2020$, the Commission amended the proposal to introduce a target of $55 \%$ reduction of the EU's GHG emissions by 2030 compared to 1990 , based on the related climate target plan [8], which was endorsed by the European Council on December $11^{\text {th }} 2020$, and called on the co-legislators to adopt the European Climate Law swiftly.

As a member of the UN, Montenegro has committed itself to achieve the U.N. Sustainable Development Goals (SDGs), while in parallel negotiating full membership in the European Union (EU) since June 2012. Of utmost importance are the negotiations in Chapter 27- Environment and climate change, opened in December 2018., while the planned fulfillment of obligations from the said Chapter (i.e., regulations, institutions, investments, infrastructure, administrative capacities), is deemed a precondition for dynamic progress in meeting SDGs, especially goals related to a green, low-carbon economy and environmental protection. Chapter 27 is connected with 40 targets of 17 SDGs [9].

In the areas of air quality and climate change, Montenegro continues to fully align with relevant EU directives, and is expected to continue doing so by regularly taking measures to decrease the level of air pollution, especially in the areas where the threshold EU values are already exceeded. Montenegro is working on the alignment of the EU legislation concerning EU Emission Trading Scheme (ETS), and is obliged to follow, report and verify GHG emissions.

On October $11^{\text {th }}, 2017$, the Parliament of Montenegro enacted a law ratifying the Paris Agreement, thus, undertaking to contribute to GHG emissions reduction globally [10]. Montenegro has committed itself to reduce $\mathrm{GHG}$ emissions by at least $1,572 \mathrm{kt} \mathrm{CO}_{2}$ eq to the level of $3,667 \mathrm{kt} \mathrm{CO}_{2}$ eq or less. Montenegro's contribution to international efforts to address CC issues, expressed through the Intended Nationally Determined Contribution (INDC) to reductions in GHG emissions, is set at a minimum of $30 \%$ by 2030 compared to 1990 as the baseline year [11]. Montenegro became a party to the Paris Agreement in December 2017 and submitted an INDC. Besides, it is essential to note that Montenegro has initiated a review of the Nationally Determined Contribution.

With the presentation of the Third National Communication on Climate Change (TNC), Montenegro is once again fulfilling its international obligations under the UNFCCC. This paper examines, forecasts and shows the causality among the GDP and greenhouse gas (GHG) emissions, expressed in $\mathrm{CO}_{2}$ eq by sectors as endogenous determinants. The sectorial division is energy, industrial processes, agriculture and land, and waste.

This essential evidence shows that governing GHG is critical in promoting sustainable growth. The main 
implications of this study suggest that energy and agriculture and land sectors are crucial in governing the emission of GHG in Montenegro.

It is the first time that a SVAR prediction of GDP and GHG emissions, is realized for the economy of Montenegro. This paper suggests using a structural vector autoregressive model, employing time series data from 2006:1 to 2017:12 for Montenegro to evaluate and compare the empirical performance of various forecasts of GDP [12].

As regards the nexus of economic growth and $\mathrm{CO}_{2}$ emissions, in the literature, there are three points of view: a) economic growth causes $\mathrm{CO}_{2}$ emissions; b) there is a bi-directional nexus between $\mathrm{CO}_{2}$ emissions and economic growth, and c) there is no causation between economic growth and $\mathrm{CO}_{2}$.

Diverse approaches and techniques have been studied to show the nexus between sustainable growth and $\mathrm{CO}_{2}$. The analysis of dynamic interrelationships of output and energy environment nexus has been examined by many authors, applying vector error correction models (VECM), panel vector autoregression (PVAR), ARDL cointegration and Granger tests, FMOLS, DOLS and impulse response function analyses $[13,14,15-22,23-28]$.

Forecasting and examining the impact of GHG on sustainable growth in Montenegro are essential for the creation and implementation of a low-carbon development strategy for the next decade. In other words, the rationale for this research is to help Montenegro cope with climate changes and develop its economy in a wise way that benefits both citizens and their natural environment and ecosystems. Factors of greenhouse gas emissions in advanced and transitional countries have been a topic of many empirical and theoretical studies. The relationship of $\mathrm{CO}_{2}$ emissions and sustainable growth has been intensive since $\mathrm{CO}_{2}$ is emitted in a number of ways such as burning of oil, coal, gas, petrol and also deforestation [29-38]. Several authors investigated relationships between economic growth and $\mathrm{CO}_{2}$ emissions using different methodologies.

A number of studies has been conducted to investigate the relationship between energy consumption, $\mathrm{CO}_{2}$ emissions, and economic development [39-42]. Many researchers examined the nexus between $\mathrm{CO}_{2}$ emissions (environmental pollution) and economic growth using the environmental Kuznets curve hypothesis: Azomahou et al. [43] found a stable relationship between economic growth and $\mathrm{CO}_{2}$ emissions by using a nonparametric kernel-based estimator to emissions for a panel of 100 countries from 1960 to 1996.

Bildirici [44] found a bi-directional link between economic growth and $\mathrm{CO}_{2}$, using panel autoregressive distributive lag model (ARDL), Fully Modified OLS Canonical Cointegration Regression, and Dynamic OLS. Song et al. [45] show that the amount of GHG and energy utilization reduce based on future planning in China, from the perspective of both the country and related sectors. Antonakakis et al. [46] found a bi-directional causal link between total economic growth and energy use, by studying the dynamic interrelationship based on output-energy-environment nexus, $\mathrm{CO}_{2}$ emissions, energy use and economic growth in the period 1971-2011. Aye and Edoja [47] showed that the correlation between $\mathrm{CO}_{2}$ and economic growth is positive for developed economies (in the high growth regime), but negative for developing economies (in the low growth regime), by using the dynamic panel threshold framework.

Mladenovic et al. [48] used a support vector machine, genetic programming, and artificial neural network to forecast the $\mathrm{CO}_{2}$ emissions and economic growth. They found that the nexus between $\mathrm{CO}_{2}$ emissions and economic growth was essential. Sun et al. [49] studied the linkage between the $\mathrm{CO}_{2}$ emissions and the lowcarbon economy using extreme learning machine and particle swarm optimization methods. They found a high forecasting performance. Bengochea-Morancho et al. [50] explored the nexus between economic growth and $\mathrm{CO}_{2}$ emissions and have shown there is a difference between advanced and other countries. Lo et al. [51] found a gap between productivity growth trends with and without $\mathrm{CO}_{2}$ emissions. Cialani [52] tested the linkage between $\mathrm{CO}_{2}$ emissions and income by using the time series data in Italy and found a positive nexus between $\mathrm{CO}_{2}$ emissions and economic growth. Sharma [53] examined the determinants of $\mathrm{CO}_{2}$ emissions in 69 countries using dynamic panel data and found out that GDP per capita and urbanization were the two main determinants of $\mathrm{CO}_{2}$ emissions. The results of Franklin and Ruth [54] for the USA, using a time series of 200 years, showed a positive linkage in per capita $\mathrm{CO}_{2}$ emissions with economic growth. Apergis and Payne [55] suggest renewable resources reduce harmful emissions.

Chaabouni et al. [56] examined the linkage between economic growth, health expenditures, and $\mathrm{CO}_{2}$ emissions. They have shown that there exists a bidirectional link between health expenditures, economic growth, and $\mathrm{CO}_{2}$ emissions except in not advanced countries. Chiu [57] investigated the relationship between real income, energy, $\mathrm{CO}_{2}$ emissions, and investment, and the outcomes of this paper have shown that clean energy usage successfully impacts real income.

Finally, Mitic et al. [58] used DOLS and FMOLS for a series of annual data of 17 transitional economies from 1997 to 2014 to analyze the relationship between real GDP and $\mathrm{CO}_{2}$ emissions and showed a long-term cointegrating relationship among $\mathrm{CO}_{2}$ emissions and real GDP, i.e., a GDP increase of $1 \%$, results in an increase of $\mathrm{CO}_{2}$ emissions of about $0.35 \%$.

On the other hand, Ozturk and Acaravci [59] examined the long-run causal relationships among economic growth, energy consumption, $\mathrm{CO}_{2}$ emissions, and employment in Turkey, using data from 1968 to 


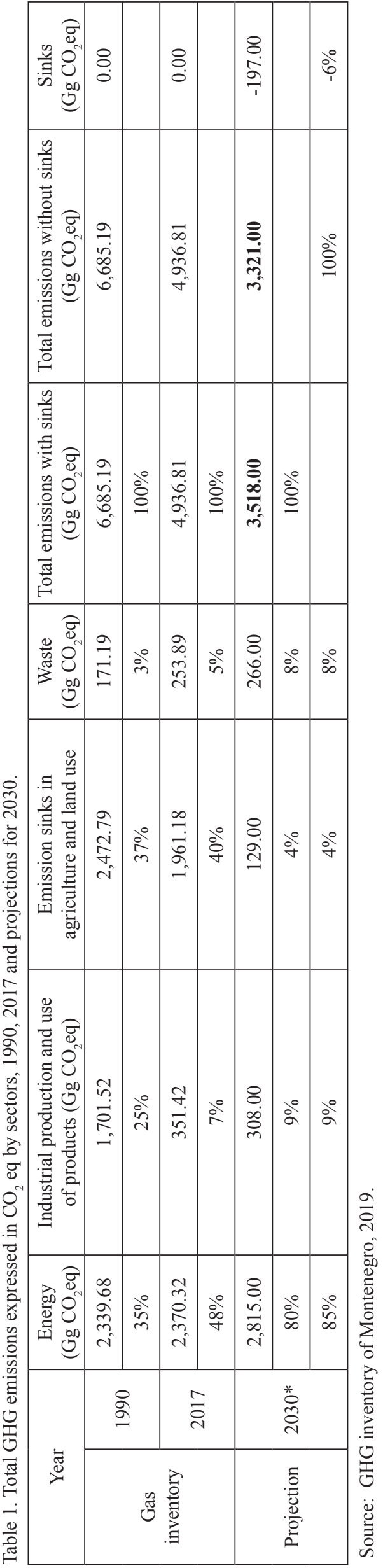

2005. Using ARDL they found that neither energy consumption per capita nor $\mathrm{CO}_{2}$ emissions cause GDP growth. Nevertheless, Mardani et al. [1] confirmed the existence of a long-run bidirectional relationship between energy consumption and $\mathrm{CO}_{2}$ emissions in both the new and old EU countries.

Given our vast literature review, we found no similar study that considered GHG emissions and economic and sustainable growth, especially using GHG emissions by sectors. Montenegro, working at the same time on UN and EU agenda, should be analytical about energy conservation policies to design appropriate strategies to deal with the reduction of $\mathrm{CO}_{2}$ emissions without impacting economic growth. Understanding the nexus between $\mathrm{CO}_{2}$ emissions and economic growth will assist the Montenegrin economy in formulating energy policies and developing energy resources in sustainable ways.

\section{Material and Methods}

We estimate a recursive structural VAR identified model of GDP. The model identifies the endogenous determinants: GDP and sectorial GHG emissions. We find that the performance of the stochastic simulation and static solution outperforms all SVAR models $[60,61]$.

The objective of this paper shows that governing GHG emissions is crucial for the sustainable development of Montenegro. Ceteris paribus, our main statement is that Montenegro should take appropriate steps in lowering the emissions of GHG, especially in the sector of energy and agriculture and land. We used a SVAR model, because as Narayan et al. [62] define it, a model is 'structural' only if we can use it to predict the effects of deliberate policy actions or of 'major' changes in the economy (positive or negative shocks). According to Sims [63] a structural model, is a model we can use in decision making. Identification is the interpretation of historically observed variation in data in a way that allows the variation to be used to predict the consequences of an action not yet undertaken.

Even though GDP determinants have been studied to a great extent, we reveal a significantly wider knowledge gap. First, conceptual specification, based on which empirical examinations of GDP determinants are analyzed, combined with GHG is not prevailing in combining theory and empirical analysis. Second, we identify a structural VAR model recursively. It has not been applied to the Montenegrin economy. VARs turn out to be one of the key empirical tools in modern macroeconomics, and they allow one to model macroeconomic data informatively [64].

According to the Montenegro GHG inventory presented in the Third National Communication on Climate Changes [2], in 2017 the largest share of emissions came from the energy sector $(48 \%$, with a growing trend in the structure), representing an increase 
of $13 \%$ since 1990 . The energy sector is followed by agriculture and land $(40 \%)$, industrial production and use of products (7\%), representing a significant decrease from 1990, and waste (5\%). The total emission with sinks is $100 \%$. In the following table, you can also see the projections for 2030, showing a significantly growing trend of emissions in the energy sector (80\%), followed by a decrease of emissions in the other observed sectors.

The most significant impact on emissions is produced by electricity and heat (including an aluminum production plant). Emissions from traffic are on the rise and are expected to continue growing, given the development of tourism in Montenegro. The main

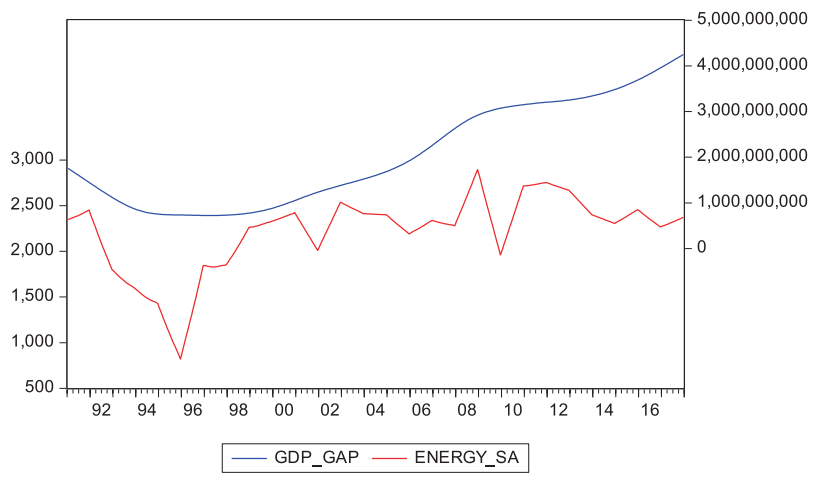

Fig. 1. GDP_GAP and Logarithm of Energy.

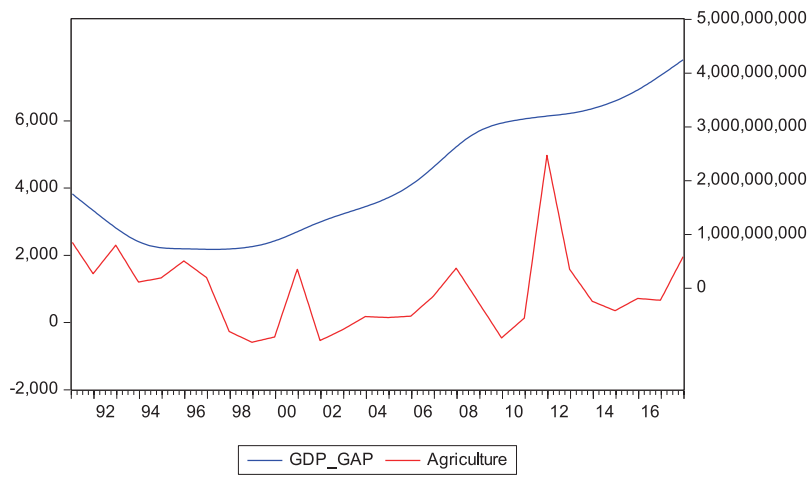

Fig. 2. GDP_GAP and Agriculture and Land.

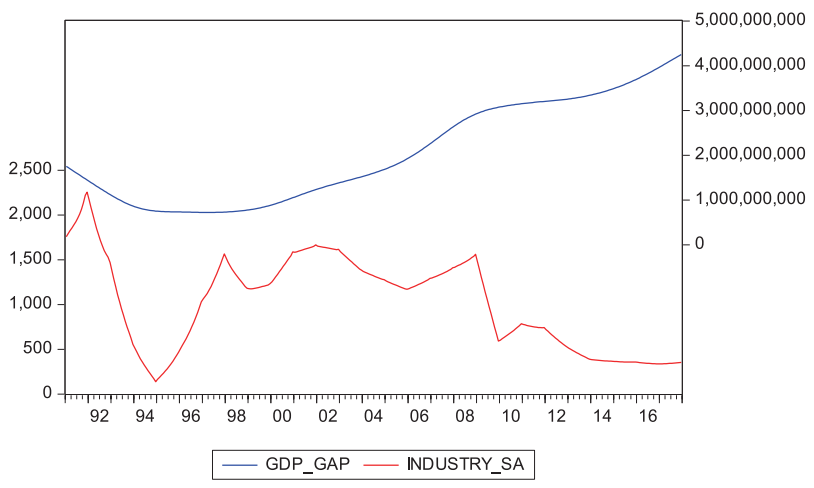

Fig. 3. GDP_GAP and Logarithm of Industrial Process. contribution to emissions from industrial processes in Montenegro is given by perfluorocarbons (PFCs) from aluminum production, which is a by-product of electrolysis.

Given that projections of GHG emissions by 2030 are increasingly concentrated in the energy sector, it is possible to analyze in more detail the dynamics of GHG emissions by sectors and its impact on GDP (potential future impact based on previous relations in the twelve years 2006-2017).

\section{Results and Discussion}

Based on the following equation (1), we formed our equation that shows parameter estimates and the main characteristics of the models. The identified recursive SVAR model is as follows:

\section{$g d p_{-} g a p_{t}=\beta_{0}+\beta_{1} \log (\text { energy })_{t}+\beta_{2} \log (\text { agriculture\&land })_{t}$ \\ $+\beta_{3} \log (\text { industrial_processes })_{t}+\beta_{4} \log (\text { waste })_{t}+u_{t}$}

...where $g d p \_g a p_{t}$ denotes the $g d p \_g a p$ rate, log natural logarithm denotes a constant elasticity,

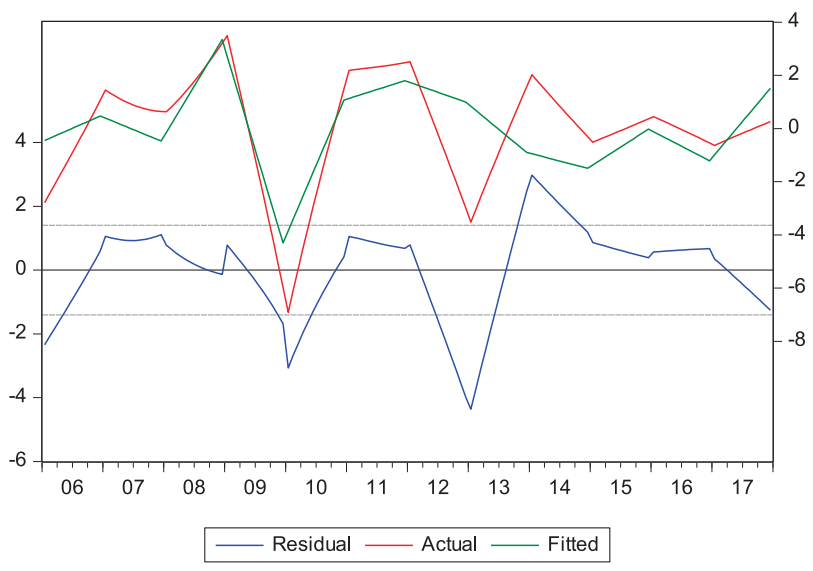

Fig. 4. Actual, fitted, and residual.

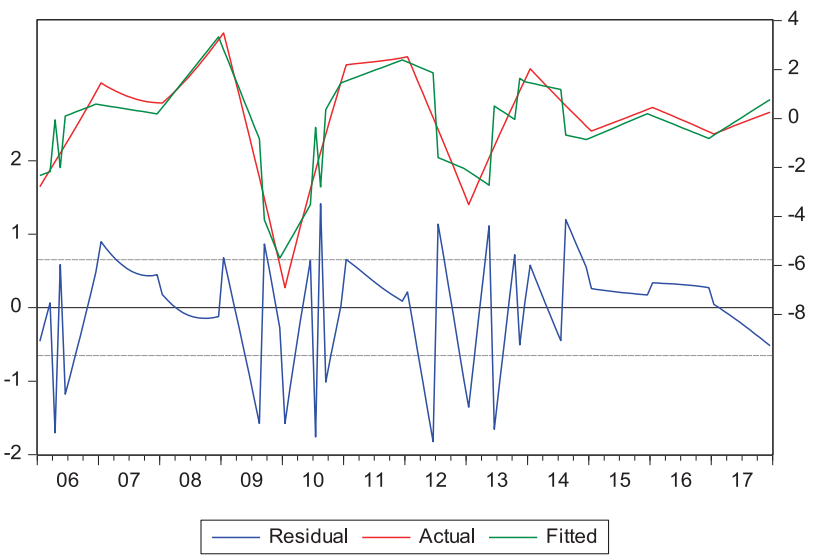

Fig. 5. Actual, fit., and residual with dich. 
Table 2. Simple Multivariate Regression of GDP with Dichotomous Variables.

\begin{tabular}{|c|c|c|c|c|}
\hline Variable & Coefficient & Std. Error & t-Statistic & Prob. \\
\hline $\mathrm{C}$ & 3.164286 & 4.172175 & 0.758426 & 0.4495 \\
\hline LOGAGRI & 0.000206 & $6.35 \mathrm{E}-05$ & 3.238851 & 0.0015 \\
\hline LOGE & 0.005700 & 0.000551 & 10.34030 & 0.0000 \\
\hline LOGINDUS & 0.000666 & 0.000157 & 4.243730 & 0.0000 \\
\hline LOGW & -0.065137 & 0.018704 & -3.482562 & 0.0007 \\
\hline D2006 & -2.027628 & 0.352732 & -5.748352 & 0.0000 \\
\hline D2010 & -2.794245 & 0.289306 & -9.658434 & 0.0000 \\
\hline D2013 & -3.371636 & 0.221644 & -15.21197 & 0.0000 \\
\hline D2014 & 1.814330 & 0.243773 & 7.442695 & 0.0000 \\
\hline R-squared & 0.892111 & \multicolumn{2}{|c|}{ Mean dependent var } & -0.010379 \\
\hline Adjusted R-squared & 0.885717 & \multicolumn{2}{|c|}{ S.D. dependent var } & 1.929412 \\
\hline S.E. of regression & 0.652252 & \multicolumn{2}{|c|}{ Akaike info criterion } & 2.043690 \\
\hline Sum squared resid & 57.43339 & \multicolumn{2}{|c|}{ Schwarz criterion } & 2.229303 \\
\hline Log likelihood & -138.1457 & \multicolumn{2}{|c|}{ Hannan-Quinn criter. } & 2.119112 \\
\hline F-statistic & 139.5354 & \multicolumn{2}{|c|}{ Durbin-Watson stat } & 1.251093 \\
\hline Prob(F-statistic) & 0.000000 & & & \\
\hline
\end{tabular}

Source: Authors' estimates.

Table 3. VAR Lag Order Selection Criteria.

\begin{tabular}{|c|c|c|c|c|c|c|}
\hline Lag & LogL & LR & FPE & AIC & SC & H.Q. \\
\hline 0 & -2901.091 & NA & $5.60 \mathrm{e}+15$ & 50.44985 & 51.04329 & 50.69075 \\
\hline 1 & -1491.185 & 2576.724 & 239167.7 & 26.57216 & 27.75905 & 27.05397 \\
\hline 2 & -1128.125 & 632.2265 & 707.2766 & 20.74353 & $\mathbf{2 2 . 5 2 3 8 7 *}$ & $\mathbf{2 1 . 4 6 6 2 4 *}$ \\
\hline 3 & -1092.526 & $\mathbf{5 8 . 9 2 1 6 3 *}$ & $\mathbf{5 9 5 . 1 4 4 5 *}$ & $\mathbf{2 0 . 5 6 0 7 9 *}$ & 22.93458 & 21.52441 \\
\hline 4 & -1086.922 & 8.792250 & 845.6914 & 20.89521 & 23.86244 & 22.09974 \\
\hline
\end{tabular}

* indicates lag order selected by the criterion Source: Authors' estimates.

$\log (\text { energy })_{t}$ the natural logarithm of energy, $\log$ (agriculture\&land), the logarithmic state of agriculture and land, $\log$ (industrial_processes) $)_{t}$ the logarithmic value of industrial processes, $\log$ (waste) $t$ denotes the natural logarithm of waste.

The time series are stationary based on visual inspection, correlograms, and unit root tests. Based on the below graph, we see graphically that gdp_gap and energy move close together, except there appears to be a break in 1996, and after 2009 the gap widens.

The same tightness is noticed between gdp_gap and agriculture and land.

The relatedness between gdp_gap and the industrial process seems to be very close from 2006 till 2010.

Simple multivariate regression shows a high linkage among the dependent and independent variables. The $\mathrm{R}^{2}$ shows $48.48 \%$ connectivity among the variables just at the beginning.

This can be confirmed from the actual, fitted, and residual graph below, but the model still needs dichotomous variables.

After adding the appropriate dichotomous variables (2006, 2010, 2013, and 2014), we get the following actual, fitted, and residual graph. It seems well-fitted, and the $\mathrm{R}^{2}$ equals $89.21 \%$, indicating that the variables explain almost $90 \%$ of the movement of GDP in Montenegro. The multivariate regression with dichotomous variables looks as following:

The SC and HQ VAR lag order selection criteria suggest 2 lags, while L.R., FPE, and AIC suggest 2 lags. After doing autocorrelation tests, we decide to go with 3 lags, VAR (3). 
Table 4. Roots of Characteristic Polynomial.

\begin{tabular}{|c|c|c|}
\hline Lags & LM-Stat & Prob \\
\hline 1 & 13.11732 & 0.9750 \\
\hline 2 & 8.904671 & 0.9987 \\
\hline 3 & 4.201667 & 1.0000 \\
\hline 4 & 4.835334 & 1.0000 \\
\hline 5 & 3.921168 & 1.0000 \\
\hline 6 & 6.982494 & 0.9999 \\
\hline 7 & 8.285785 & 0.9993 \\
\hline 8 & 4.802020 & 1.0000 \\
\hline 9 & 8.546036 & 0.9991 \\
\hline 10 & 9.365479 & 0.9980 \\
\hline
\end{tabular}

Probs from chi-square with 25 df. Source: Authors' estimates.

Table 5. VAR Residual Serial Correlation L.M. Tests.

\begin{tabular}{|c|c|c|}
\hline Lags & LM-Stat & Prob \\
\hline 1 & 13.11732 & 0.9750 \\
\hline 2 & 8.904671 & 0.9987 \\
\hline 3 & 4.201667 & 1.0000 \\
\hline 4 & 4.835334 & 1.0000 \\
\hline 5 & 3.921168 & 1.0000 \\
\hline 6 & 6.982494 & 0.9999 \\
\hline 7 & 8.285785 & 0.9993 \\
\hline 8 & 4.802020 & 1.0000 \\
\hline 9 & 8.546036 & 0.9991 \\
\hline 10 & 9.365479 & 0.9980 \\
\hline
\end{tabular}

Probs from chi-square with 25 df. Source: Authors' estimates.

In the meantime, the test performed in Table 4 shows that VAR (3) is stationary, and we can move further with our analysis.

Based on Fig. 6, there appears to be no autocorrelation. This is confirmed by the L.M. test in Table 5 .

The null hypothesis of no serial correlation cannot be rejected as long as up to 10 lags the $p$-value is higher than $5 \%$.

Our VAR (3) estimates with 3 lags is employed for further analysis. We estimate from 2006:1 till 2015:12 and leave 2016 and 2017 for out-of-sample forecasting performances.

In the following figure we show the forecasting performance of deterministic simulation and dynamic solution.

Fig. 7 reveals important results that show that under deterministic simulation and dynamic solution, which uses forecasted and not real values, our model is able to forecast well the endogenous variables of our VAR (3) except agriculture and land (which turns back in the second quarter of 2017).

In case we perform the forecasting using a fan chart, we can observe the forecast and graphical representation of forecast uncertainty around it. It allows for error, coefficient, and the uncertainty associated with explanatory variables in the model. Moreover, it demonstrates a confidence interval of the forecast for every period in the forecast horizon. The darkest area shows the confidence interval assuming economic conditions stay the same. The lightest area is $90 \%$ confidence interval. It is symmetric, depending on the types of risks, the model we adopted for the variance, and the assumptions regarding the exogenous variables. Bands expand with forecast horizon and stabilize on unconditional confidence interval. If the errors are normal and the model is linear, the fan chart will be symmetrical around the mean: 1s.e. bounds correspond to $\sim 60 \%$ confidence interval, and 2 s.e. bounds correspond to $95 \%$ confidence interval. In the meantime, the errors are bootstrapped, i.e., selected randomly from the estimated residuals, and coefficient uncertainty expands the bounds. As we get more data to calibrate the model, we should expect the confidence interval to shrink.

So far, we have not seen any causality among the variables, GDP and GHG emissions expressed in $\mathrm{CO}_{2}$ eq by sectors. This would lead us to impulse responses and variance decomposition.

The response of GDP_GAP to agriculture and land, and all other GHG emissions expressed in $\mathrm{CO}_{2}$ eq, a shock goes through oscillations, from positive to negative. The positive shock of agriculture and land increases the GDP in the first 10 months to 0.28 , then decreases sharply to -0.18 after 2 years. How can we interpret the above results? In the beginning, when the agriculture and land greenhouse gas increase, as a result of higher investments in unmanaged agricultural production, the GDP increases, but only seasonally. At the same time, the medium-run dynamic impact of the innovation of greenhouse gases produced by agriculture and land causes the GDP to decrease sharply.

A much more substantial impact is noticed in the sector of energy in the first half of the year, after being hit by the energy shock. The energy sector is the primary source of anthropogenic GHG emissions. The energy sector includes all activities referring to the combustion of fuels (solid, liquid, gaseous, and biofuels) in stationary and mobile sources, as well as fugitive emissions from fuels. Fugitive emissions occur during the production, transmission, processing, storage, and distribution of fossil fuels. As a result of investments in the sector of energy, the GDP_GAP increases by $0.43 \%$ in the first 6 months. After 12 months, the dynamic effects of the greenhouse gas emissions from energy reduce the GDP_GAP to 0.02 , and after 17 months to -0.24 . 

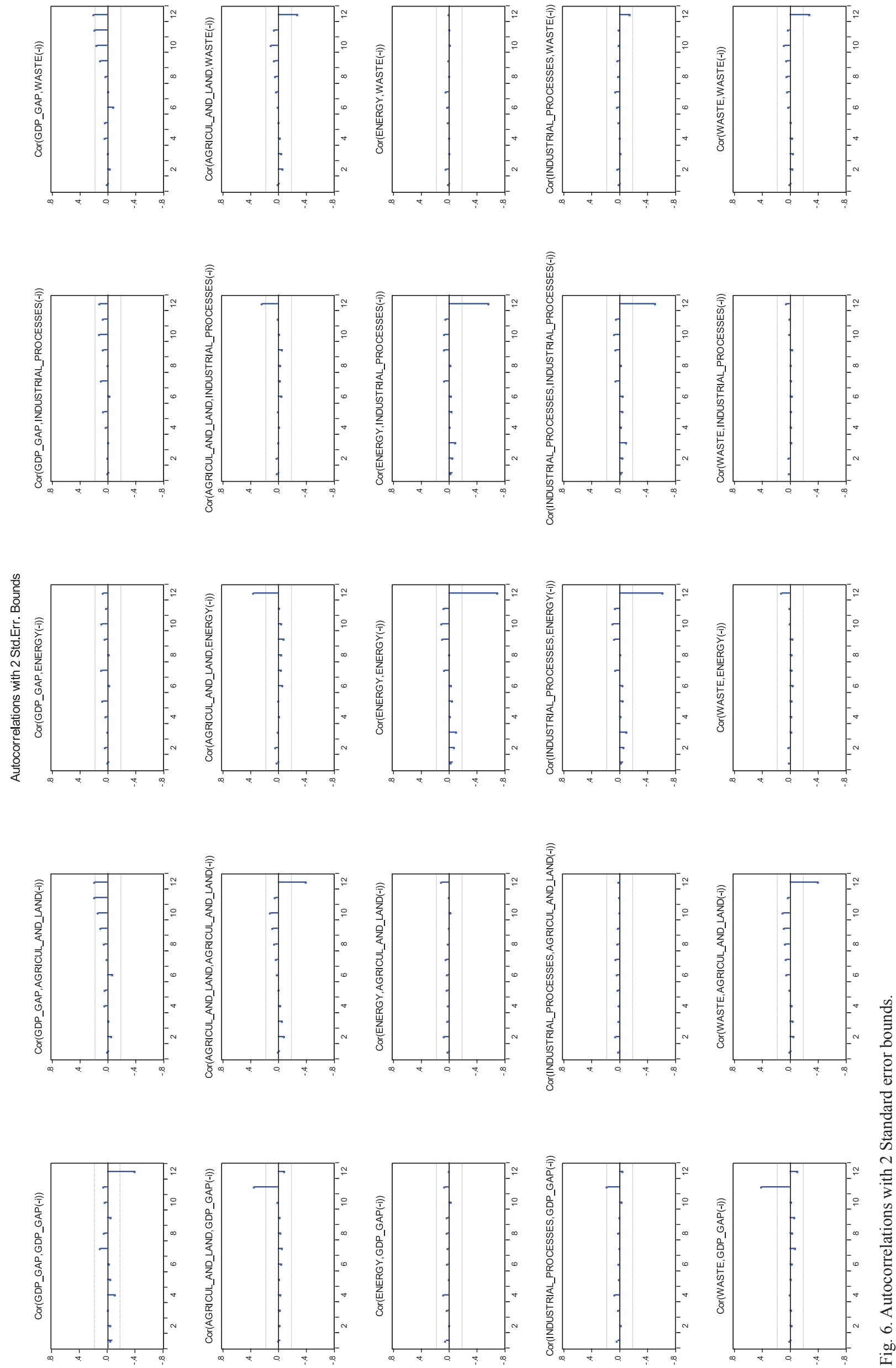
GDP_GAP

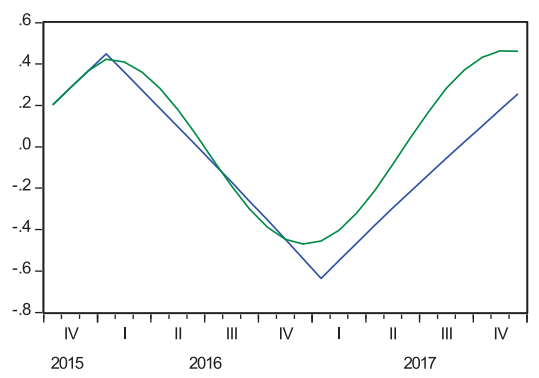

- Actual —GDP_GAP (Baseline)

LOGE

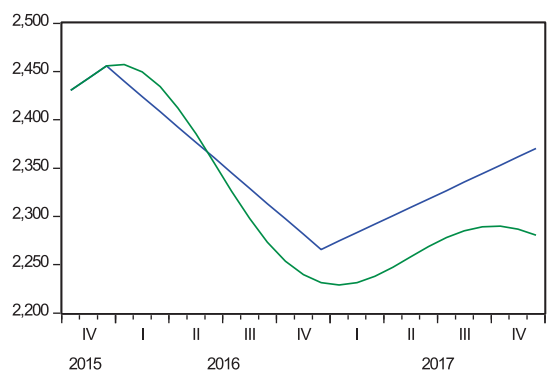

- Actual — LOGE (Baseline)
LOGAGRI

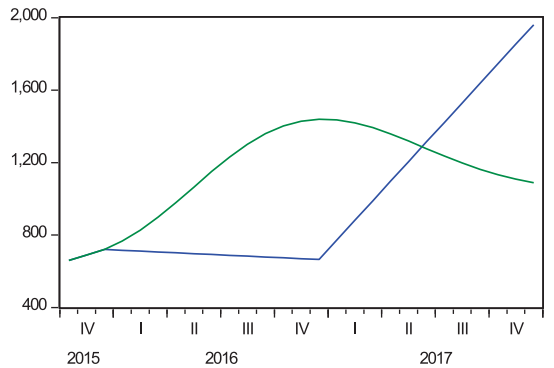

- Actual — LOGAGRI (Baseline)

LOGINDUS

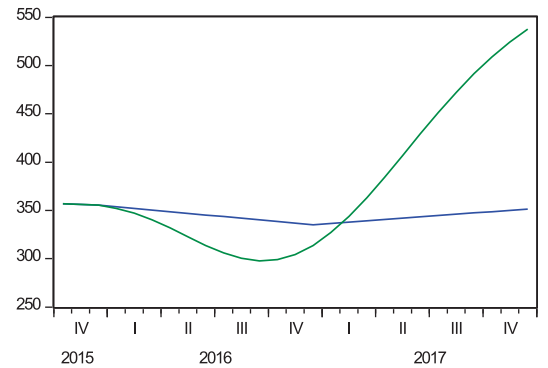

- Actual — LOGINDUS (Baseline)
LOGW

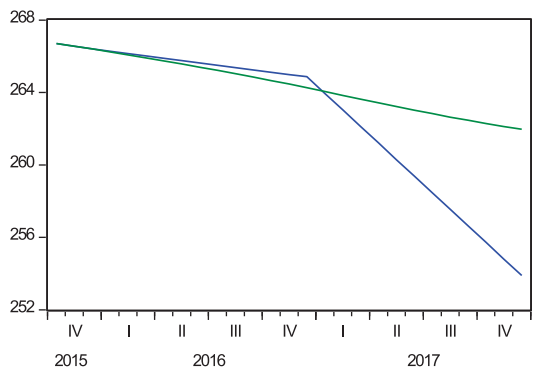

- Actual — LOGW (Baseline)

Fig. 7. Deterministic simulation and dynamic solution (2006:1-2017:12).

The response of GDP_GAP to the industrial process has the same pattern of movement as in the previous greenhouse gas shocks, but it is stronger. After the investments made in the Montenegrin economy by the industrial sector, the GDP GAP increases to 0.12 in the first 7 months. From the $7^{\text {th }}$ month, the GDP_GAP decreases to 0.00 after 26 months gradually.

Interestingly, the GDP_GAP decreases at the very beginning from a waste shock to -0.02 in the first 3 months. After this point, the dynamic effects show a smooth increase in the GDP_GAP to 0.07 after 14 months, and then a slight decrease again. Why the increase from the $3^{\text {rd }}$ to the $14^{\text {th }}$ month? The waste management takes advantage of the disposal and treatment of solid municipal waste, wastewater management, and waste incineration in the period 3-14 months. Still, after this period, the methane $\left(\mathrm{CH}_{4}\right)$ emissions resulting from the disposal and treatment of solid municipal waste and the emissions of nitrogen sulfide $\left(\mathrm{N}_{2} \mathrm{O}\right)$ cause the GDP_GAP to decrease.

For policymakers, it is of high value to retreat the variance decomposition in time dynamics.

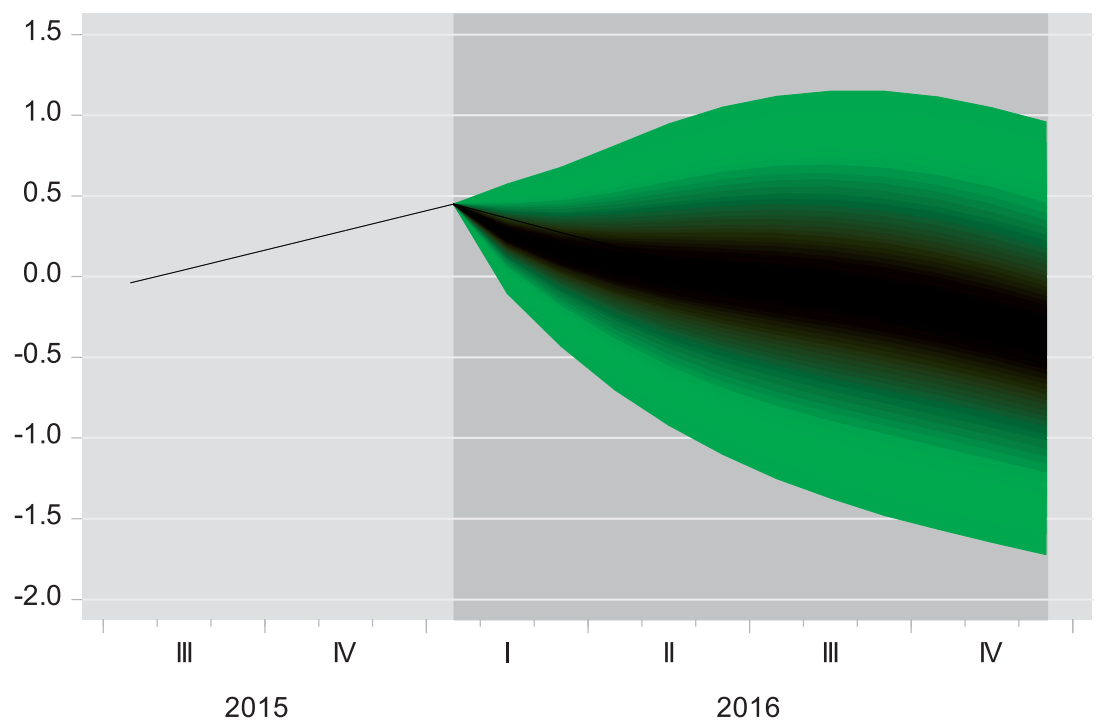

Fig. 8. Fan chart of GDP_GAP. 
Response of GDP_GAP to GDP_GAP

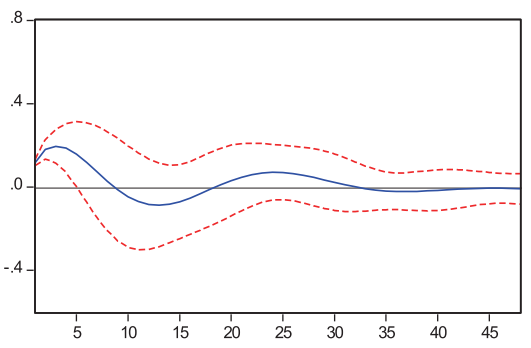

Response of GDP_GAP to LOGE

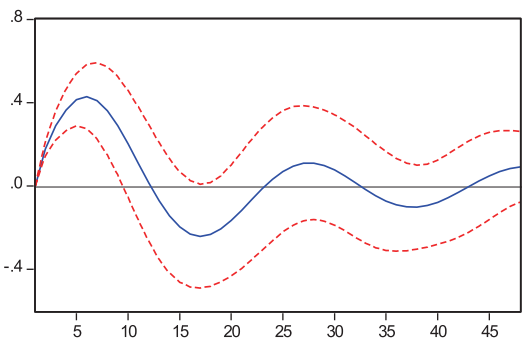

Response of GDP_GAP to LOGAGR

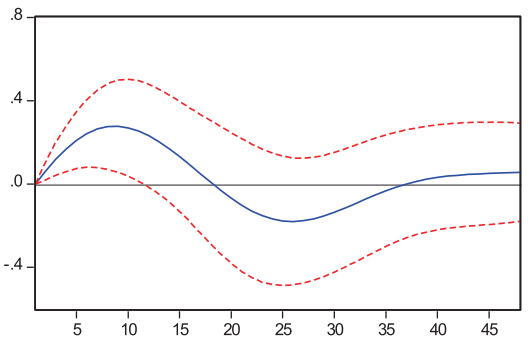

Response of GDP_GAP to LOGINDUS

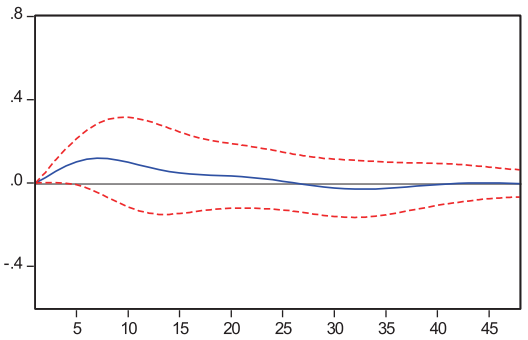

Response of GDP_GAP to LOGW

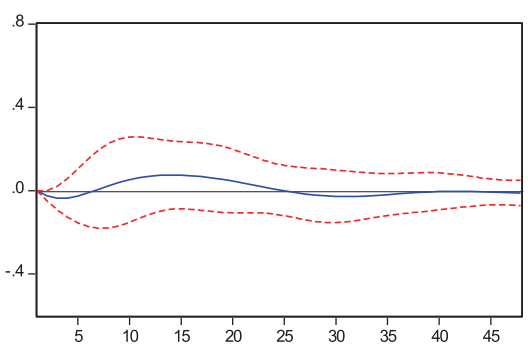

Fig. 9. GDP_GAP Impulse response to Cholesky One S.D. Innovations \pm S.E.

The forecast error variance of GDP is mostly the result of shocks to itself at short horizons $98.88 \%$. After a 6 month-horizon, the contribution of agriculture and land shocks to the movement of GDP increase to $13.43 \%$. The contribution of energy shocks jumps to $62.27 \%$, while the contribution of industrial and waste rises to 3.71 and 0.16 , respectively. We notice from the above decomposition that the energy sector plays a crucial role in the forecast error variance of GDP. It is essential to mention that the contribution of agriculture and land increases its impact on the decomposition of GDP over time, and it reaches $29.63 \%$ at the end of the 24-month horizon. Only the sectors of agriculture and land and energy contribute with $83.41 \%$ to the movement of GDP at the 24-month horizon. In the SVAR model (structural vector autoregressive model), it is possible to analyze the impact of $\mathrm{CO}_{2}$ emissions by sectors on the movement of GDP in Montenegro. In the research that covered the period 2006-2017, the following conclusions were reached regarding the variables, i.e., the factors that most determine the future dynamics of GDP. Emissions from the energy sector mainly influence the decomposition of GDP variance: the contribution of emissions from the energy sector

Table 6. Variance decomposition of GDP_GAP.

\begin{tabular}{|c|c|c|c|c|c|c|}
\hline Period & S.E. & LOGAGRI & LOGE & LOGINDUS & LOGW & GDP_GAP \\
\hline 1 & 0.118216 & 0.734594 & 0.043001 & 0.007794 & 0.331353 & 98.88326 \\
\hline 2 & 0.288097 & 2.575477 & 36.04288 & 0.941471 & 0.258412 & 60.18176 \\
\hline 3 & 0.473273 & 5.673452 & 49.82823 & 1.852263 & 0.351436 & 42.29462 \\
\hline 4 & 0.654160 & 8.326933 & 56.47889 & 2.594508 & 0.303623 & 32.29605 \\
\hline 5 & 0.824407 & 10.87296 & 60.33863 & 3.207592 & 0.221949 & 25.35887 \\
\hline 6 & 0.974274 & 13.43029 & 62.27358 & 3.713899 & 0.159286 & 20.42295 \\
\hline 7 & 1.098156 & 16.05205 & 62.74830 & 4.128601 & 0.139003 & 16.93205 \\
\hline 8 & 1.194678 & 18.75932 & 62.07943 & 4.467530 & 0.170205 & 14.52351 \\
\hline 9 & 1.265667 & 21.51692 & 60.53404 & 4.743852 & 0.254493 & 12.95069 \\
\hline 10 & 1.315555 & 24.21476 & 58.41523 & 4.964168 & 0.388781 & 12.01706 \\
\hline 11 & 1.350398 & 26.66816 & 56.09669 & 5.127984 & 0.565459 & 11.54171 \\
\hline 12 & 1.376562 & 28.65124 & 53.99817 & 5.230669 & 0.771967 & 11.34795 \\
\hline
\end{tabular}

Source: Authors' estimates. 

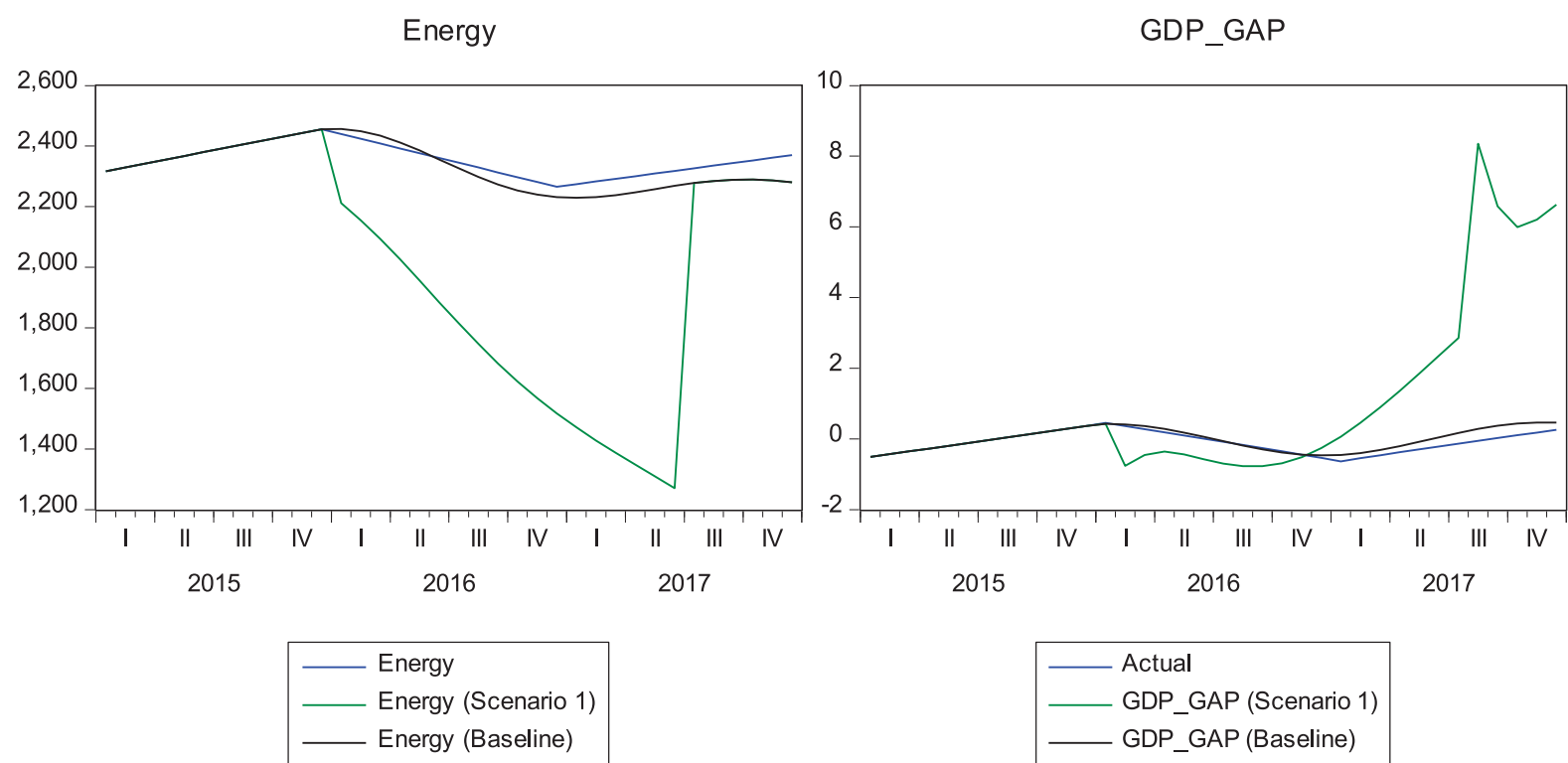

Fig. 10. Forecasting of GDP_GAP: alternative scenario of energy decrease from - 10 to $-44 \%$.

to GDP ranges from $37.04 \%$ to $62.1 \%$ in the dynamics of the first year of the forecast. The contribution of emissions from the agriculture and land management sectors ranges from $2.5 \%$ to $28.6 \%$ in the dynamics of the first year of GDP forecast error variance.

The contribution of emissions from the industrial sector to GDP grows from $0.94 \%$ to $5.23 \%$ in the dynamics of the first year of the forecast, which is in line with the projections of the relative growth of emissions in the energy sector relative to the industrial sector (gradual limitation of stationary emissions in the industry). The contribution of waste sector emissions to GDP growth is also growing, which confirms the thesis that the rate of recycling and reuse of waste does not increase with satisfactory dynamics concerning the absolute growth of waste.

Since the central policymakers for sustainable development are interested to see sensitivity scenarios, we insert the decrease of energy GHG from $-10 \%$ to $-44 \%$, in the period of 2016:1-2017:6 under deterministic-dynamic solution. This scenario is based on the following key points: a) the expected increase of investments into the energy sector, given the need to produce energy from renewable sources, which implies large investments and b) that the energy sector has the biggest share of GHG emissions, as stated in the GHG inventory table and its explanation.

As can be seen in the graph, in the scenario of reducing $\mathrm{CO}_{2}$ emissions from the energy sector from $2,434.87 \mathrm{Gg} \mathrm{CO}_{2}$ eq to $1,270.43 \mathrm{Gg} \mathrm{CO}_{2}$ eq $(44 \%)$ in the period from the first to the eighteenth month of the forecast, GDP would grow dynamically, respectfully from $0.06 \%$ to $8.4 \%$. In other words, as early as one year after reducing emissions, the low-carbon economy would begin to record dynamic and strong growth (with a reduction in the remediation of environmental degradation costs). In other words, the stated reduction of emissions significantly stimulates the dynamics of GDP growth and changing the sector's contributions to growth. Based on the analyzed time series, the energy sector increases its share in emissions, at the same time, most significantly contributing to the dynamics of GDP growth, compared to other sectors relevant to emissions. Antonakakis et al. [46] did a similar study to ours, which revealed that the effects of the various types of energy consumption on economic growth and emissions are heterogeneous on the various groups of 106 countries in the sample, and also found a bidirectional causality between total economic growth and energy consumption. Han et al. [32] argue that bidirectional short-run causality between $\mathrm{CO}_{2}$ emissions and GDP are the signal to develop a low-carbon economy needed to address the dilemma between economic development and carbon emissions. Hossain and Chen [41] showed that economic structure and emission elements are liable to increase carbon emissions in the industrial sector, which implies that the energy policymakers should be more mindful. Nathaniel et al. [65] suggest that nonrenewable energy increases emissions which negatively affects environmental quality. In order to achieve environmental sustainability, which is in line with the SDG 7, adoption of renewable energy sources like biogas, geothermal, solar, wave power, and so forth, is needed. Sebri and Salha [26] confirm bidirectional causality flow between economic growth and renewable energy consumption for BRIC countries,validating the feedback hypothesis. Cerovic Smolovic et al. [66] results confirm the existence of a positive relationship between economic growth and renewable energy consumption in the long term in old and new EU Member States.

As can be seen in Fig. 10, in case we hypothetically decrease the GHG emissions in the energy sector, from 2,434.87 $\mathrm{Gg} \mathrm{CO}_{2}$ eq to $1,270.43$, in the period from 
January 2016 till June 2017, the GDP GAP increases sharply from 0.062 in January 2017 to 8.355 in August 2017.

We decreased the energy sector, and the forecasted GDP increased sharply thus, implying that government regulations are essential. The impulse response findings reveal that the response of GDP to a shock in energy, industrial processes, agriculture and land use, and waste management is significant. The variance decomposition of GDP is moved mostly from energy and agriculture and land use. The energy refers to the combustion of fuels (solid, liquid, gaseous, and biofuels) in stationary and mobile sources, as well as fugitive emissions from fuels. The agricultural sector refers to enteric fermentation, fertilizer management, cumulative and other sources of gas from the soil, and biomass burning emissions. Mandatory application of the sustainable forest management requirements is crucial in forestry sector.

Investing in clean, renewable energy sources can prove to be beneficial for economic growth, which is compatible with the findings of Chiu and Chang [67]. As we have shown, simply by reducing GHG emissions in the energy sector, in the long run we can boost the GDP growth rate.

\section{Conclusions}

With the indispensable need for sustainability and the ever-growing need for environmental quality, some adjustments in the economy's structure are needed. Montenegro should focus on innovative development by increasingly investing in technological innovation and should promote clean production, renewable energy, energy efficiency and circular economy. The Government should not only provide policy and financial support by aligning environmental laws and regulations with the EU and its enforcement but should also improve education on green growth for which the implementation of new ideas and strategies that are based on green investment is necessary.

Structural vector autoregression, from an empirical viewpoint, reveals valuable information for policymakers. We selected a model, aggregating vital macroeconomic variables to forecast GDP and GHG emission in Montenegro. The forecasting performance of deterministic-dynamic solution reveals an excellent forecasting performance, even though it uses forecasted values, adding errors to the forecast. On the other hand, the stochastic-static performs a significant prediction of our VAR (3) model.

We find that among the performance of the forecasts, the stochastic simulation - static solution has the best performance, having the baselines within the confidence bands, thus, ensuring us that the VAR(3) can predict the GDP based on GHG emissions expressed in $\mathrm{CO}_{2}$ eq by sectors as endogenous determinants.
This essential evidence shows that governing GHG is critical in promoting sustainable growth. The main implications of this study suggest that energy and agriculture and land use sectors are crucial in regulating the emission of GHG in Montenegro. In other words: the underlying objective of the paper relates to governing GHG emissions of energy and agriculture and land use as conducive to sustainable growth in Montenegro.

In sum, the empirical conclusions of this paper provide macroprudential policymakers with an in-depth understanding of the role GHG emission determinants play in sustainable development and the growth of the Montenegrin economy. Future research avenues might include sign restrictions, Bayesian, and factor augmented VARX approaches of other pollutants to get a better macro-econometric picture of the GHG emissions and sustainable growth.

The objective of this paper was that Montenegro should take appropriate steps in lowering the emissions of GHG, especially in the sector of energy and agriculture and land use. Given the presented points of view regarding the nexus of economic growth and $\mathrm{CO}_{2}$ emissions, we have demonstrated that, for Montenegro, there is a bi-directional nexus between $\mathrm{CO}_{2}$ emissions and economic growth.

Based on the obtained results, it is recommended that the policymakers in Montenegro should strive to adopt and implement strategies that should focus on adopting environmentally friendly technologies, i.e. best available techniques to decrease $\mathrm{CO}_{2}$ emissions. Policymakers should continue controlling GHG emissions, as well as introduce incentives to reduce emissions, i.e. green financing measures, in order to meet their emission reduction targets, as per international agreements.

In addition, given that Montenegro has ratified the Paris Agreement, and that is simultaneously working on both the EU and UN agenda, obligations arising from Chapter 27 - Environment and climate change, as well as 40 targets of SDGs with which this Chapter is associated, shows progress, and positively affects the Montenegrin economy, demonstrated through the GDP growth rate.

During the period 2017-2030, Montenegro's goal is to continue to reduce GHG emissions without jeopardizing economic growth. Some of the measures that should help in achieving that goal are: (i) Energy sector: energy efficiency measures, increased share of energy from renewable sources, energy production and distribution sector modernization; (ii) Industry sector: improvement of industrial technologies and processes; (iii) Transport: promotion of electric vehicles usage; (iv) Agriculture: supporting organic production, as well as the usage of organic manure; (v) Land use: limiting quantities for felling in state and private forests, reducing burned areas on an annual basis and (vi) Waste sector: reducing the share of bio-waste and promoting recycling/composting. 


\section{Conflict of Interest}

The authors declare no conflict of interest.

\section{Referencess}

1. MARDANI A., STREIMIKIENE D., CAVALLARO F., LOGANATHAN N., KHOSHNOUDI M. Carbon dioxide $\left(\mathrm{CO}_{2}\right)$ emissions and economic growth: A systematic review of two decades of research from 1995 to 2017. Science of the Total Environment, 649, 31, 2019.

2. GOVERNMENT OF MONTENEGRO. Montenegro Third National Communication on Climate Change. Available online: http://eusluge.euprava.me/eParticipacija/GetFile. aspx?Id=657 (accessed on 10 June 2020).

3. UNFCCC. Paris Agreement. Available online: https:// unfccc.int/files/essential_background/convention/ application/pdf/english_paris_agreement.pdf (accessed on 10 June 2020).

4. UNFCCC. Paris Agreement - Status of Ratification, 21st Conference of the Parties. Available online: https://doi.org/ FCCC/CP/2015/L.9 (accessed on 20 May 2020).

5. UNITED NATIONS. United States of America: Withdrawal. Available online: https://treaties.un.org/doc/ Publication/CN/2019/CN.575.2019-Eng.pdf (accessed on 27 June 2020).

6. EUROPEAN COMMISSION. Communication from the Commission to the European Parliament, the European Council, the Council, the European Economic and Social Committee and the Committee of the Regions, The European Green Deal. Available online: https://eurlex.europa.eu/resource.html?uri=cellar:b828d165-1c2211ea-8c1f-01aa75ed71a1.0002.02/DOC_1\&format=PDF (accessed on 27 June 2020).

7. EUROPEAN ENVIRONMENT AGENCY. Trends and projections in Europe 2019. Available online: https://www. eea.europa.eu/publications/trends-and-projections-ineurope-1 (accessed on 15 May 2020).

8. EUROPEAN COMMISSION. Proposal for a Regulation of the European Parliament and of the Council establishing the framework for achieving climate neutrality and amending Regulation (EU) 2018/1999 (European Climate Law). Available online: https://eur-lex.europa.eu/legalcontent/EN/TXT/PDF/?uri=CELEX:52020PC0080\&from $=$ EN (accessed on 20 December 2020)

9. UNITED NATIONS DEVELOPMENT PROGRAMME (UNDP) IN MONTENEGRO, \& GOVERNMENT OF MONTENEGRO. Unravelling connections : EU Accession and the 2030 Agenda. Available online: http://www.un.org. me/Library/DaO-UNDAF/Unraveling Connections - EU Accession and the 2030 Agenda, 2018.pdf (accessed on 29 June 2020).

10. MINISTRY OF SUSTAINABLE DEVELOPMENT AND TOURISM (MSDT) MONTENEGRO, Montenegro - Second biennial update report on climate change 2019. Available online: https://www4. unfccc.int/sites/SubmissionsStaging/NationalReports/ Documents/5937861_Montenegro-BUR2-1-SECOND BIENNIAL UPDATE REPORT ON CLIMATE CHANGE_Montenegro.pdf (accessed on 23 May 2020).

11. MINISTRY $\overline{\text { OF SUSTAINABLE DEVELOPMENT }}$ AND TOURISM (MSDT) MONTENEGRO. Technology needs assessment for climate change mitigation and adaptation for Montenegro: National strategy and action plan. Available online: http://www.unfecc.me/uploads/ Dokumenta/TNA_Montenegro_final-ENG.pdf (accessed on 23 May 2020).

12. HENDRY D.F., CLEMENTS M.P. Pooling of forecasts. The Econometrics Journal, 7 (1), 1, 2004.

13. APERGIS N., PAYNE J. E., MENYAH K., WOLDERUFAEL Y. On the causal dynamics between emissions, nuclear energy, renewable energy, and economic growth. Ecological Economics, 69 (11), 2255, 2010.

14. CHANG C. C. A multivariate causality test of carbon dioxide emissions, energy consumption and economic growth in China. Applied Energy, 87 (11), 3533, 2010.

15. CHIOU-WEI S. Z., CHEN C.F., ZHU Z. Economic growth and energy consumption revisited - Evidence from linear and nonlinear Granger causality. Energy Economics, 30 (6), 3063, 2008.

16. CHONTANAWAT J., HUNT L.C., PIERSE R. Does energy consumption cause economic growth?: Evidence from a systematic study of over 100 countries. Journal of Policy Modeling, 30 (2), 209, 2008.

17. COWAN W.N., CHANG T., INGLESI-LOTZ R., GUPTA $\mathrm{R}$. The nexus of electricity consumption, economic growth and $\mathrm{CO}_{2}$ emissions in the BRICS countries. Energy Policy, 66, 359, 2014.

18. DAGHER L., YACOUBIAN T. The causal relationship between energy consumption and economic growth in Lebanon. Energy Policy, 50, 795, 2012.

19. DERGIADES T., MARTINOPOULOS G., TSOULFIDIS L. Energy consumption and economic growth: Parametric and non-parametric causality testing for the case of Greece. Energy Economics, 36, 686, 2013.

20. DINÇ D.T., AKDOĞAN E.C. Renewable energy production, energy consumption and sustainable economic growth in Turkey: A VECM approach. Sustainability (Switzerland), 11 (5), 1273, 2019.

21. FURUOKA F. The $\mathrm{CO}_{2}$ emissions-development nexus revisited. Renewable and Sustainable Energy Reviews, 51, 1256, 2015.

22. GHOSH S. Electricity supply, employment and real GDP in India: evidence from cointegration and Grangercausality tests. Energy Policy, 37 (8), 2926, 2009.

23. KOOP G., PESARAN M. H., POTTER S. M. Impulse response analysis in nonlinear multivariate models. Journal of Econometrics, 74 (1), 119, 1996.

24. LONG X., NAMINSE E.Y., DU J., ZHUANG J. Nonrenewable energy, renewable energy, carbon dioxide emissions and economic growth in China from 1952 to 2012. Renewable and Sustainable Energy Reviews, 52, 680, 2015.

25. PAYNE J.E. A survey of the electricity consumptiongrowth literature. Applied Energy, 87 (3), 723, 2010.

26. SEBRI M., BEN-SALHA O. On the causal dynamics between economic growth, renewable energy consumption, $\mathrm{CO}_{2}$ emissions and trade openness: Fresh evidence from BRICS countries. Renewable and Sustainable Energy Reviews, 39, 14, 2014.

27. STERN D. I. The Rise and Fall of the Environmental Kuznets Curve. World Development, 32 (8), 1419, 2004.

28. YILDIRIM E., SUKRUOGLU D., ASLAN A. Energy consumption and economic growth in the next 11 countries: The bootstrapped autoregressive metric causality approach. Energy Economics, 44, 14, 2014.

29. ALAM M.M., MURAD M.W., NOMAN A.H.M., OZTURK I. Relationships among carbon emissions, economic growth, energy consumption and population growth: Testing Environmental Kuznets Curve hypothesis 
for Brazil, China, India and Indonesia. Ecological Indicators, 70, 466, 2016.

30. BEKHET H.A., MATAR A., YASMIN T. CO2 emissions, energy consumption, economic growth, and financial development in GCC countries: Dynamic simultaneous equation models. Renewable and Sustainable Energy Reviews, 70, 117, 2017.

31. CHAUDHARY R., BISAI S. Factors influencing green purchase behavior of millennials in India. Management of Environmental Quality: An International Journal, 29 (5), 798, 2018.

32. HAN J., DU T., ZHANG C., QIAN X. Correlation analysis of $\mathrm{CO}_{2}$ emissions, material stocks and economic growth nexus: Evidence from Chinese provinces. Journal of Cleaner Production, 180, 395, 2018.

33. HE J. Pollution haven hypothesis and environmental impacts of foreign direct investment: The case of industrial emission of sulfur dioxide $\left(\mathrm{SO}_{2}\right)$ in Chinese provinces. Ecological Economics, 60 (1), 228, 2006.

34. KOFI ADOM P., BEKOE W., AMUAKWA-MENSAH F., MENSAH J.T., BOTCHWAY E. Carbon dioxide emissions, economic growth, industrial structure, and technical efficiency: Empirical evidence from Ghana, Senegal, and Morocco on the causal dynamics. Energy, 47 (1), 314, 2012.

35. RITI J.S., SONG D., SHU Y., KAMAH M. Decoupling $\mathrm{CO}_{2}$ emission and economic growth in China: Is there consistency in estimation results in analyzing environmental Kuznets curve? Journal of Cleaner Production, 166, 1448, 2017.

36. ROBAINA-ALVES M., MOUTINHO V., COSTA R. Change in energy-related $\mathrm{CO}_{2}$ (carbon dioxide) emissions in Portuguese tourism: A decomposition analysis from 2000 to 2008. Journal of Cleaner Production, 111 (B), 520, 2016.

37. ZHANG Y. ., BIAN X.J., TAN W., SONG J. The indirect energy consumption and $\mathrm{CO}_{2}$ emission caused by household consumption in China: an analysis based on the input-output method. Journal of Cleaner Production, 163, 69, 2017.

38. ZHAO X., ZHANG X., LI N., SHAO S., GENG Y. Decoupling economic growth from carbon dioxide emissions in China: A sectoral factor decomposition analysis. Journal of Cleaner Production, 142 (4), 3500, 2017.

39. DOGAN E., ASLAN A. Exploring the relationship among $\mathrm{CO}_{2}$ emissions, real GDP, energy consumption and tourism in the EU and candidate countries: Evidence from panel models robust to heterogeneity and cross-sectional dependence. Renewable and Sustainable Energy Reviews, 77 (March), 239, 2017.

40. GARDINER R., HAJEK P. Interactions among energy consumption, $\mathrm{CO}_{2}$, and economic development in European Union countries. Sustainable Development, 28 (4), 723, 2020.

41. HOSSAIN M.A., CHEN S. Decoupling of energy-related $\mathrm{CO}_{2}$ emissions from economic growth: a case study of Bangladesh. Environmental Science and Pollution Research, 27 (17), 20844, 2020.

42. WANG M.L., WANG W., DU S.Y., LI C.F., HE Z. Causal relationships between carbon dioxide emissions and economic factors: Evidence from China. Sustainable Development, 28 (1), 73, 2019.

43. AZOMAHOU T., LAISNEY F., NGUYEN VAN P. Economic development and $\mathrm{CO}_{2}$ emissions: A nonparametric panel approach. Journal of Public Economics, 90 (6-7), 1347, 2006.

44. BILDIRICI M.E. The effects of militarization on biofuel consumption and $\mathrm{CO} 2$ emission. Journal of Cleaner Production, 152, 420, 2017.

45. SONG J., YANG W., WANG S., WANG X., HIGANO Y., FANG K. Exploring potential pathways towards fossil energy-related GHG emission peak prior to 2030 for China: An integrated input-output simulation model. Journal of Cleaner Production, 178, 688, 2018.

46. ANTONAKAKIS N., CHATZIANTONIOU I., FILIS G. Energy consumption, $\mathrm{CO}_{2}$ emissions, and economic growth: An ethical dilemma. Renewable and Sustainable Energy Reviews, 68 (1), 808, 2017.

47. AYE G.C., EDOJA P.E. Effect of economic growth on $\mathrm{CO}_{2}$ emission in developing countries: Evidence from a dynamic panel threshold model. Cogent Economics and Finance, 5 (1), 1, 2017

48. MLADENOVIC I., SOKOLOV-MLADENOVIC S., MILOVANCEVIC M., MARKOVIC D., SIMEUNOVIC $\mathrm{N}$. Management and estimation of thermal comfort, carbon dioxide emission and economic growth by support vector machine. Renewable and Sustainable Energy Reviews, 64, 466, 2016

49. SUN W., WANG C., ZHANG C. Factor analysis and forecasting of $\mathrm{CO}_{2}$ emissions in Hebei, using extreme learning machine based on particle swarm optimization. Journal of Cleaner Production, 162, 1095, 2017.

50. BENGOCHEA-MORANCHO A., HIGÓN-TAMARIT F., MARTÍNEZ-ZARZOSO I. Economic growth and $\mathrm{CO}_{2}$ emissions in the European Union. Environmental and Resource Economics, 19 (2), 165, 2001.

51. LO S.F., SHEU H.J., HU J.L. Taking $\mathrm{CO}_{2}$ emissions into a country's productivity change: The Asian growth experience. International Journal of Sustainable Development and World Ecology, 12 (3), 279, 2005.

52. CIALANI C. $\mathrm{CO}_{2}$ emissions, GDP and trade: a panel cointegration approach. International Journal of Sustainable Development and World Ecology, 24 (3), 193, 2017.

53. SHARMA S.S. Determinants of carbon dioxide emissions: Empirical evidence from 69 countries. Applied Energy, 88 (1), 376, 2011

54. FRANKLIN R.S., RUTH M. Growing up and cleaning up: The environmental Kuznets curve redux. Applied Geography, 32 (1), 29, 2012.

55. APERGIS N., PAYNE J.E. Renewable and non-renewable energy consumption-growth nexus: Evidence from a panel error correction model. Energy Economics, 34 (3), 733, 2012.

56. CHAABOUNI S., ZGHIDI N., BEN MBAREK M. On the causal dynamics between $\mathrm{CO}_{2}$ emissions, health expenditures and economic growth. Sustainable Cities and Society, 22, 184, 2016

57. CHIU Y. BIN. Carbon dioxide, income and energy: Evidence from a non-linear model. Energy Economics, 61, 279, 2017

58. MITIC P., MUNITLAK-IVANOVIC O., ZDRAVKOVIC A. A cointegration analysis of real GDP and $\mathrm{CO}_{2}$ emissions in transitional countries. Sustainability (Switzerland), 9 (4), 568, 2017.

59. OZTURK I., ACARAVCI A. $\mathrm{CO}_{2}$ emissions, energy consumption and economic growth in Turkey. Renewable and Sustainable Energy Reviews, 14 (9), 3220, 2010. 
60. SMITH J., WALLIS K.F. A simple explanation of the forecast combination puzzle. Oxford Bulletin of Economics and Statistics, 71 (3), 331, 2009.

61. STOCK J.H., WATSON M.W. Combination forecasts of output growth in a seven-country data set. Journal of Forecasting, 23 (6), 405, 2004v

62. NARAYAN P.K., NARAYAN S., PRASAD A. A structural VAR analysis of electricity consumption and real GDP: Evidence from the G7 countries. Energy Policy, 36 (7), 2765, 2008.

63. SIMS C.A. Are Forecasting Models Usable for Policy Analysis? Federal Reserve Bank of Minneapolis Quarterly Review, 10 (1), 2, 1986.

64. DEL NEGRO M. Bayesian Macroeconometrics. In The Oxford Handbook of Bayesian Econometrics; John Geweke, Gary Koop, Herman Van Dijk, Eds., Oxford University Press: Oxford, England, 1, 2012.
65. NATHANIEL S., BARUA S., HUSSAIN H., ADELEYE $\mathrm{N}$. The determinants and interrelationship of carbon emissions and economic growth in African economies: Fresh insights from static and dynamic models. Journal of Public Affairs, (October 2019), 1, 2020.

66. CEROVIĆ SMOLOVIĆ J., MUHADINOVIĆ M., RADONJIĆ M., ĐURAŠKOVIĆ J. How does renewable energy consumption affect economic growth in the traditional and new member states of the European Union? Energy Reports, 6, 505, 2020.

67. CHIU C.L., CHANG T.H. What proportion of renewable energy supplies is needed to initially mitigate $\mathrm{CO} 2$ emissions in OECD member countries? Renewable and Sustainable Energy Reviews, 13 (6-7), 1669, 2009. 